\title{
Effect of pruning on Jatropha curcas L. seedlings during the nursery stage
}

\author{
Noda-Leyva, Yolai ${ }^{1}$; Pérez-Vázquez, Arturo ${ }^{2 *}$; Martín-Martín, Giraldo Jesús ${ }^{1}$; \\ Martín- Alonso, Gloria Marta ${ }^{3}$ \\ 1 Universidad de Matanzas Camilo Cienfuegos, Estación Experimental de Pastos y Forrajes Indio Hatuey, \\ Central España Republicana, Perico, Matanzas, Cuba. \\ 2 Colegio de Postgraduados, Campus Veracruz, Km. 88.5, Carretera Federal Xalapa-Veracruz, CP 91690, \\ Apartado Postal 421, Veracruz, México. \\ 3 Instituto Nacional de Ciencias Agrícolas, Mayabeque, Cuba. \\ * Correspondence: parturo@colpos.mx
}

\begin{abstract}
Objective To determine the effect of pruning on seedlings of Jatropha curcas L. during the nursery stage. Design/Methodology/Approach. To determine the effect of pruning on Jatropha curcas L. seedlings during the nursery stage, a study was carried out at the nursery of the CPA "Abel Santamaría" of the Martí municipality, Cuba. A complete randomized design was used. Three treatments (T) were tested: 1) control (without pruning), 2) pruning $30 \mathrm{~cm}$ above the soil and seedling defoliation, 3) pruning $30 \mathrm{~cm}$ above the soil and without seedling defoliation. A descriptive analysis was carried out to determine the survival, regrowth, and number of plants with primary branches. For the number of leaves and branches, height, and diameter, a simple analysis of variance was used, with partitions for each observation.

Results. No treatment influenced the survival and regrowth of the plant: up to 2 branches of T2 and T3 were obtained per plant. A greater height was recorded with $\mathrm{T} 1(38.63 \mathrm{~cm})$ and this result is different from T2 and T3. The highest number of branches that formed primary branches was obtained by pruning and without defoliation (28 vs. 22 and 0, for T2 and T1, respectively).

Study Limitations/Implications. Pruning is an option that can increase Jatropha's agronomic yield, but it has not been studied under nursery conditions.

Findings/Conclusions. The pruning of $J$. curcas seedlings at $30 \mathrm{~cm}$ above the ground, under nursery conditions, with or without defoliation, does not affect the survival or regrowth of the crops and the development of the primary branches. However, more plants with primary branches and a wider stem diameter can be obtained by pruning without defoliation.
\end{abstract}

Gitation: Noda-Leyva, Y., PérezVázquez, A., Martín-Martín, G. J., \& Martín- Alonso, G. M. (2021). Effect of pruning on Jatropha curcas L. seedlings during the nursery stage. Agro Productividad. https://doi.org/10.32854/ agrop.v14i12.2000

Editor in Chief: Dr. Jorge Cadena Iñiguez

Received: April 20, 2021. Accepted: November 11, 2021. Published on-line: December 30, 2021.

Agro Productividad, 14(12). December. 2021. pp: 165-171.

This work is licensed under a Creative Commons Attribution-NonCommercial 4.0 International license.
Keywords: defoliation, survival, regrowth, biofuels.

\section{INTRODUCTION}

Jatropha curcas (L.) is a shrub of the Euphorbiaceae family, native to Central America. Its seeds contain up to $35 \%$ oil, which can be processed to produce high-quality raw material for biofuels and specialized products (García et al., 2017).

This monoecious plant has male and female flowers in the same inflorescence and sporadically develops hermaphrodite flowers. Generally, the inflorescence is a terminal panicle: the female flowers are located in the center of the inflorescence and the male flowers, in the periphery (Dasumiati et al., 2017). In addition, the panicles are only found at the terminal ends of the plant. Therefore, the yield of the harvest will depend on the number of terminals per plant. Pruning is very important and plays a fundamental role in the production of flowers and the subsequent fruit yield (Senger, 2018).

Pruning in Jatropha allows plants to have a greater number of branches and a proportionally higher production, allows a good penetration of the solar radiation, 
facilitates the passage of the wind, strengthens the productive branches, regulates the size of the plants, facilitates the manual collection of fruits, and eliminates damaged or unproductive branches (Muñoz et al., 2016; Lamonarca, 2017).

The study refers to the effect of pruning during the establishment and production phase of the seedlings (Díaz, 2015). Consequently, determining the morphological response during the nursery phase should be one of the first research areas; this is quite important for the subsequent management of productive plantations.

Therefore, the aim of this work was to evaluate the effect of different pruning practices on Jatropha curcas L. seedlings during the nursery stage.

\section{MATERIALS AND METHODS}

The study was carried out in the nursery of the Abel Santa María CPA, located in the municipality of Martí, Matanzas province, Cuba, from March to June 2014. During the study period, a $376.4-\mathrm{mm}$ rainfall and $23.9^{\circ} \mathrm{C}$ mean temperature were recorded.

We used $20 \mathrm{~cm} \times 12 \mathrm{~cm}$ perforated black polyethylene bags, which were filled with a mixture of soil $(70 \%)$ and organic matter $(30 \%)$.

Design and treatments: A complete randomized design was used. Thirty repetitions were evaluated per treatment. Three treatments were studied: 1) control (without pruning), 2) pruning at $30 \mathrm{~cm}$ above the soil and seedling defoliation, 3) pruning at $30 \mathrm{~cm}$ above the soil without seedling defoliation.

Experimental procedure: Two seeds were sown per bag, using the "Cabo Verde" provenance harvested at the "Indio Hatuey" Estación Experimental de Pastos y Forrajes. All the material planted in the nursery received a daily morning irrigation $(4 \mathrm{~L} /$ minute/ $\mathrm{m}^{2}$ ) to guarantee the emergence and development of the seedlings. When they reached an average height of $7 \mathrm{~cm}$, thinning was carried out to select the most vigorous seedling per bag.

When the seedlings reached a height of $60-70 \mathrm{~cm}, 60$ days after sowing, they were pruned according to the indicated treatments.

Registered variables: To evaluate survival, regrowth, and the number of new leaves, weekly samplings were carried out seven days after the pruning. One-hundred twenty days after sowing optimal condition, seedlings were transplanted to the field. Overall, eight measurements were made during the period. The number of plants that formed primary branches and the number of branches were evaluated, based on visual counting, from the second observation.

A measuring tape was used to determine the height: i.e., the distance from the base of the stem (ground) to the end of the highest branch. A vernier caliper was used to measure the thickness of the seedlings in the main stem at a height of $20 \mathrm{~cm}$ (Campuzano, 2009). Both measurements were made from the third week after pruning.

Statistical Analysis: A descriptive analysis was carried out for the survival, regrowth of plants, and number of plants that formed primary branches indicators; meanwhile, the number of leaves, new branches, height, and thickness were subject to a simple analysis of variance with partitions for each observation. The compliance with the homogeneity of variances and normal distribution assumptions were first verified. The Infostat statistical 
package, version 1.1, was used. The means were compared using Duncan's test (1955) with a $\mathrm{p} \leq 0.05$ significance level.

\section{RESULTS AND DISGUSSION}

Figure 1 shows the survival of the seedlings by pruning effect. No treatment was determined to influence this variable; one hundred percent of the study plants survived with all treatments in each observation. This result indicates that the response was independent of the evaluated management.

It has been determined that pruning has had a variable effect on the survival of other trees. For example, in a study carried out on Nothofagus nervosa by Donoso et al. (2009), 82\% survival was obtained in the first year when apical cuts were applied. However, Guacín (2014) demonstrated that, when this technique was applied to Prosopis sp., there was no mortality among the trees.

In the case of $J$. curcas, no studies related to pruning during the nursery phase were found. However, the objective of this agricultural practice is to guarantee the development of more branches for fruit production and to shape the structure of the plant from an early age. Therefore, establishing that this agricultural management did not affect survival was of great importance.

Figure 2 shows the effect of pruning on the regrowth of seedlings. For this variable, no significant differences were found between treatments. The applied technique did not have a determinant effect on the regrowth of any of the plants.

This result was different from the findings of Bacab et al. (2012) for other trees such as Leucaena leucocephala, in which pruning had a significant effect on regrowth.

South (2016) recognized that pruning young plants leaves them more vulnerable to stress, as a consequence of the removal of biomass. In addition, South argues that, if seedlings survive, they will require large amounts of resources to recover (regrowth). When this criterion is compared with the results obtained in this study, only contradictory speculations can be made. The specific response of this species shows no evidence of handling-induced stress; the various pruning techniques did not affect the behavior of the

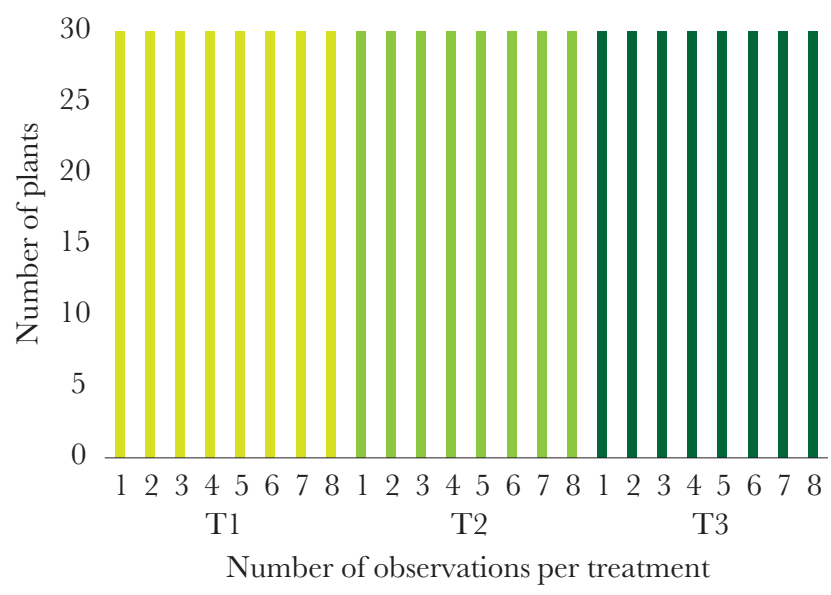

Figure 1. Effect of pruning on seedlings survival. 


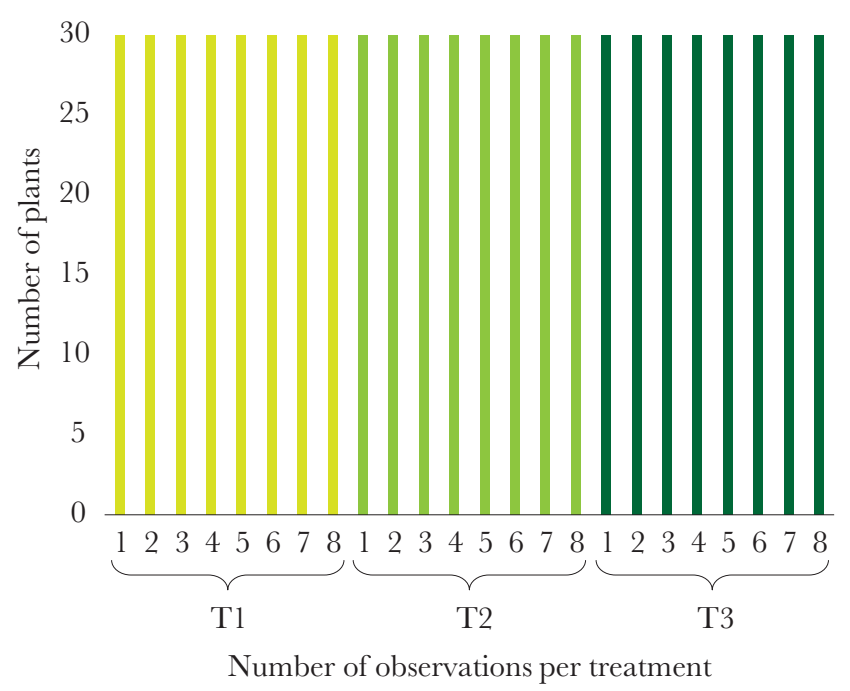

Figure 2. Effect of pruning on the regrowth of seedlings.

plants. However, studies about the subject are deficient or null; therefore, providing a cropbased physiological explanation is difficult.

During the whole study, the plants did not stop growing new leaves (Table 1). Significant differences were found at each moment between the evaluated treatments $(p<0.05)$. However, the response was variable in each observation. From the first to the third week, treatment 3 grew the highest number of leaves; in week 4, it did not statistically differ from treatment 2; afterwards, the latter recorded the greater number of leaves during

Table 1. Behavior of some morphological variables after pruning.

\begin{tabular}{|c|c|c|c|c|c|c|c|c|c|}
\hline \multirow{2}{*}{ Variables } & \multirow{2}{*}{ Treatments } & \multicolumn{8}{|c|}{ Sampling } \\
\hline & & 1 & 2 & 3 & 4 & 5 & 6 & 7 & 8 \\
\hline Leaves (number) & $\begin{array}{l}1 \\
2 \\
3\end{array}$ & $\begin{array}{l}3^{\mathrm{c}} \\
4^{\mathrm{b}} \\
5^{\mathrm{a}}\end{array}$ & $\begin{array}{l}5^{\mathrm{c}} \\
6^{\mathrm{b}} \\
7^{\mathrm{a}}\end{array}$ & $\begin{array}{l}6^{\mathrm{c}} \\
7^{\mathrm{b}} \\
8^{\mathrm{a}}\end{array}$ & $\begin{array}{l}7^{\mathrm{b}} \\
8^{\mathrm{a}} \\
8^{\mathrm{a}}\end{array}$ & $\begin{array}{l}7^{\mathrm{c}} \\
9^{\mathrm{a}} \\
8^{\mathrm{b}}\end{array}$ & $\begin{array}{l}7^{\mathrm{c}} \\
9^{\mathrm{a}} \\
8^{\mathrm{b}}\end{array}$ & $\begin{array}{l}7^{\mathrm{b}} \\
9^{\mathrm{a}} \\
9^{\mathrm{a}}\end{array}$ & $\begin{array}{l}7^{\mathrm{b}} \\
9^{\mathrm{a}} \\
9^{\mathrm{a}}\end{array}$ \\
\hline \multicolumn{2}{|l|}{ Standard error $(+)$} & $0.33^{*}$ & $0.50 *$ & $0.50 *$ & $0.53 *$ & $0.50 *$ & $0.44 *$ & $0.44 *$ & $0.40^{*}$ \\
\hline Branches (number) & $\begin{array}{l}1 \\
2 \\
3\end{array}$ & $\begin{array}{l}- \\
- \\
-\end{array}$ & $\begin{array}{l}0^{\mathrm{c}} \\
2^{\mathrm{a}} \\
1^{\mathrm{b}}\end{array}$ & $\begin{array}{l}0^{\mathrm{c}} \\
2^{\mathrm{a}} \\
1^{\mathrm{b}}\end{array}$ & $\begin{array}{l}0^{\mathrm{c}} \\
2^{\mathrm{a}} \\
1^{\mathrm{b}}\end{array}$ & $\begin{array}{l}0^{\mathrm{c}} \\
2^{\mathrm{a}} \\
1^{\mathrm{b}}\end{array}$ & $\begin{array}{l}0^{\mathrm{b}} \\
2^{\mathrm{a}} \\
2^{\mathrm{a}}\end{array}$ & $\begin{array}{l}0^{\mathrm{b}} \\
2^{\mathrm{a}} \\
2^{\mathrm{a}}\end{array}$ & $\begin{array}{l}0^{\mathrm{b}} \\
2^{\mathrm{a}} \\
2^{\mathrm{a}}\end{array}$ \\
\hline \multicolumn{2}{|l|}{ Standard error $(+)$} & - & $0.12^{*}$ & $0.07 *$ & $0.09 *$ & $0.08 *$ & $0.11 *$ & $0.06^{*}$ & $0.08^{*}$ \\
\hline Height (cm) & $\begin{array}{l}1 \\
2 \\
3\end{array}$ & $\begin{array}{l}- \\
- \\
-\end{array}$ & $\begin{array}{l}- \\
- \\
-\end{array}$ & $\begin{array}{l}28.40^{\mathrm{a}} \\
16.47^{\mathrm{c}} \\
21.71^{\mathrm{b}}\end{array}$ & $\begin{array}{l}31.30^{\mathrm{a}} \\
18.17^{\mathrm{c}} \\
24.70^{\mathrm{b}}\end{array}$ & $\begin{array}{l}32.45^{\mathrm{a}} \\
22.51^{\mathrm{c}} \\
26.10^{\mathrm{b}}\end{array}$ & $\begin{array}{l}33.93^{\mathrm{a}} \\
26.77^{\mathrm{c}} \\
27.10^{\mathrm{b}}\end{array}$ & $\begin{array}{l}36.00^{\mathrm{a}} \\
27.90^{\mathrm{c}} \\
28.53^{\mathrm{b}}\end{array}$ & $\begin{array}{l}38.63^{\mathrm{a}} \\
29.30^{\mathrm{b}} \\
29.57^{\mathrm{b}}\end{array}$ \\
\hline \multicolumn{2}{|l|}{ Standard error $(+)$} & - & - & $1.04 *$ & $1.16^{*}$ & $1.05^{*}$ & $1.14 *$ & $1.11 *$ & $1.05^{*}$ \\
\hline Stem thickness $(\mathrm{cm})$ & $\begin{array}{l}1 \\
2 \\
3\end{array}$ & $\begin{array}{l}- \\
- \\
-\end{array}$ & $\begin{array}{l}- \\
- \\
-\end{array}$ & $\begin{array}{l}0.80^{\mathrm{b}} \\
0.83^{\mathrm{b}} \\
0.94^{\mathrm{a}}\end{array}$ & $\begin{array}{l}0.80^{\mathrm{b}} \\
0.83^{\mathrm{b}} \\
0.94^{\mathrm{a}}\end{array}$ & $\begin{array}{l}0.85^{\mathrm{b}} \\
0.88^{\mathrm{b}} \\
0.97^{\mathrm{a}}\end{array}$ & $\begin{array}{l}0.86^{\mathrm{b}} \\
0.88^{\mathrm{b}} \\
0.97^{\mathrm{a}}\end{array}$ & $\begin{array}{l}0.86^{\mathrm{c}} \\
0.90^{\mathrm{b}} \\
0.99^{\mathrm{a}}\end{array}$ & $\begin{array}{l}0.90^{\mathrm{b}} \\
0.94^{\mathrm{b}} \\
0.99^{\mathrm{a}}\end{array}$ \\
\hline \multicolumn{2}{|l|}{ Standard error $(+)$} & - & - & $0.03^{*}$ & $0.03 *$ & $0.05^{*}$ & $0.05 *$ & $0.03 *$ & $0.04^{*}$ \\
\hline
\end{tabular}

Means with a common letter are not significantly different $(\mathrm{p} \leq 0.05)$. \pm standard error $(\mathrm{E}$ st).

Average with a common letter is not significantly different $(\mathrm{p} \leq 0.05)$. 
the observations corresponding to fifth and sixth weeks. Subsequently no differences with respect to treatment 3 in the penultimate and last weeks were recorded; therefore, both techniques have a positive influence in the development of new formed leaves, since unpruned plants were the ones in which this variable was least developed.

Walteros et al. (2013) found similar results by pruning young Vitis vinifera plants; they were able to stimulate the growth of biomass in the aerial part. Guacín (2014) also highlighted the positive effect of pruning on the formation of leaves and shoots of Prosopis sp., since the first weeks of the crop. According to Basave et al. (2014), not all species respond to pruning techniques, since growth and branching patterns vary from one plant family to another.

The highest number of branches formed was remarkable from the second week in the plants to which pruning and stripping (treatment 2) were applied and it differed significantly $(\mathrm{p}<0.05)$ from the rest of the treatments until the sixth week. Subsequently, for observations 7 and 8 , no significant differences were found in the plants that were pruned, but not defoliated. For both treatments, up to 2 branches per plant were formed at the end of the nursery stage (week 8). Unpruned plants (treatment 1) did not grow branches during the evaluation time.

Meanwhile, these results corroborate the criteria of Riikonen and Luoranen (2018) by stating that the number of leaves in a tree are partially the result of the presence of primary branches - a characteristic that was observed in this study. The treatments with the highest number of primary branches were also those with the highest number of leaves.

The lack of pruning (treatment 1) resulted in the highest plants (Table 1) in each observation and the height differed significantly from the rest of the treatments.

At the end of the evaluation period, the unpruned plants reached an average height of $38.63 \mathrm{~cm}$, taller than the pruned plants, which reached 29.30 and $29.57 \mathrm{~cm}$, for treatments 2 and 3 , respectively.

Umeki et al. (2018) consider that this is a normal physiological behavior, because - when the apical shoots of the plants are cut - the "apical dominance" stops and a stimulation of cell division and a higher concentration of nutrients and enzymes in the lateral branches take place.

In each of the observations, significant differences in stem diameter (Table 1) were also found between treatments. It was notable that treatment 3 -in which pruning was applied, but no defoliation took place - always obtained the thickest stems.

These results do not match those obtained by Hoyos and Hurtado (2017) for the cultivation of the papaya (Carica papaya), which show that unpruned plants had a wider stem diameter. The difference in the response could have various causes: different plant families, the effect of the genotype-environment interaction, the handling or the applied techniques, among others. Nevertheless, the positive response to this variable is known to be of great importance for all species, since it translates into greater nutrient reserves that guarantee the development and growth of the crop (Basave et al., 2021)

Determining which of the applied techniques provided the highest number of plants that formed primary branches (Table 2) was an important measure. Establishing the proper handling that gradually shapes the productive structure of Jatropha curcas in the nursery stage will guarantee that other pruning can be carried out during the establishment and 
Table 2. Number of plants that formed primary branches according to the effect of pruning.

\begin{tabular}{c|c}
\hline Treatment & Number of plants that formed primary branches \\
\hline 1 & 0 \\
\hline 2 & 22 \\
\hline 3 & 28 \\
\hline
\end{tabular}

development phase of the crop. Therefore, the number of branches can proportionally increase with regard to a greater production of fruits per plant.

Table 2 shows that, by pruning and not defoliating (treatment 3), more plants with primary branches (28 vs. 22 and 0 ) were formed. This is perhaps related to the presence of the leaves that carry out the photosynthesis process. This could have favored the elongation of the shoots that subsequently became branches (Chávez et al., 2017).

In general terms, the present study verified the positive response of Jatropha curcas when it is pruned during the nursery stage. All the plants survived the handling; it was possible to start the conformation and development of primary branches from an early age, without affecting the biological cycle of the crop.

\section{CONGLUSIONS}

The results of this research showed that Jatropha curcas seedlings can be pruned during their nursery stage, $30 \mathrm{~cm}$ above the ground, with or without defoliation techniques; neither impacts the survival or regrowth of the crop and the development of primary branches. However, more plants with primary branches and a thicker stem were obtained, when they were pruned, but not defoliated.

\section{ACKNOWLEDGEMENT}

The authors would like to thank the Fomento de fincas integrales agro-energéticas autosustenables para contribuir al desarrollo sostenible en zonas rurales de Cuba international project, funded by the OIKOS cooperação e desenvolvimento NGO, Portugal, Code PT-2007-DRD-2711329485.

\section{REFERENGES}

Bacab, H. M.; Solorio, F. J. y Solorio, S. B. (2012). Efecto de la altura de poda en Leucaena leucocephala y su influencia en el rebrote y rendimiento de Panicum máximum. Revista Avance en Investigación Agropecuaria. 16(1): 65-77.

Basave, E.; López, M. A.; Cetina, V. M.; Aldrete, A. y Almaraz, J. (2014). Prácticas culturales en vivero que influyen en la calidad de planta de Enterolobium cyclocarpum. Revista Bosque 35 (3): 301-309.

Basave, E.; Cetina, V.; López, M. A.; Ramírez, C.; Trejo, C. y Conde, V. (2021). La poda aérea como práctica cultural en vivero para Caesalpinea coriaria (Jacq.) Willd. Revista Mexicana de Ciencias Forestales Vol. 12 (63): 138-152 DOI: https://doi.org/10.29298/rmcf.v12i63.799

Campuzano, L.F. (2009). Perspectivas de la investigación de Jatropha curcas L. en Colombia parte I: Componente genético. Revista Facultad Nacional de Agronomía. Medellín, 62. (3): 1-9.

Chávez, E. Y.; Rodríguez, G.; Enríquez, J. R.; Velasco, V. A. y Gómez, M. (2017). Compartimentos de biomasa aérea en rodales de Pinus oaxacana bajo tratamientos silvícolas. Madera y Bosques. 23 (3): 147-161.

Dasumiati, Miftahudin, Triadiati, Hartana, A. (2017). Morphological and Growth Characters of Andromonoecious Jatropha curcas. Advances in Intelligent Systems Research (AISR), volume 149: 133-139. http://creativecommons.org/licenses/by-nc/4.0/ 
Díaz, I. A. (2015). Efecto de podas y fertilización sobre la curva de producción de piñón (Jatropha curcas); finca San Luis, Retalhuleu. Tesis para optar por el título de Ingeniero Agrónomo. Universidad Rafael Landívar. 53 p.

Donoso, P.; Soto, D. y Gerding, V. (2009). Efectos de la poda de tallo y fertilización de liberación controlada en vivero sobre el comportamiento de plántulas de Nothofagus nervosa en terreno. Revista Bosque. 30 (1): 48-53.

Duncan, D.B. (1955). Multiple range and multiple F. test. Biometrics. 11:1.

García, Florencia; García, E.; Pérez, A. \& Ruíz, O. (2017). Contenido de aceite en accesos de Jatropha curcas L. no tóxica en Veracruz, México. Rev. Mex. Cienc. Agríc. 8 (3):635-648.

Guacín, M. A. (2014). Respuesta a la poda del árbol de Campeche (Prosopis sp.) en la región oriental de Guatemala. Tesis para optar por el título de Licenciado en Zootecnia. Universidad de San Carlos de Guatemala. 61 p.

Hoyos, J. y Hurtado, A. (2017). Efecto de la poda temprana de brotes laterales en el inicio de la floración de papaya Tainung. Temas agrarios. 22 (2): 54-60.

Lamonarca, F. (2017). Los árboles frutales. Editorial De Vecci, S. A. Parkstone International. 256 p.

Muñoz, J. A.; Hilario, M.; Delgado, G.; Rivera, M. y Jacobo, María del Rosario. (2016). Niveles de poda en el cultivo de Higuera (Ficus carica L.) para la región de zonas áridas. Agrofaz. 16 (2): 43-50.

Riikonen, J. and J. Luoranen. (2018). Seedling Production and the Field Performance of Seedlings. Forests 9: 740. Doi: 10.3390/f9120740.

Senger, Elisa. (2018). Characterization and management of Jatropha curcas L. germplasm. Dissertation submitted to the Faculty of Agricultural Sciences Institute of Plant Breeding, Seed Science and Population Genetics University of Hohenheim. 59 p.

South, D. B. (2016). Top Pruning of bareroot hardwood seedlings. Tree Planters' Notes 59 (2): 37-48. https://rngr. net/publications/tpn/59-2/top-pruning-ofbareroot-hardwood-seedlings.

Umeki, K., M. Kawasaki, N. Shigyo and T. Hirao. (2018). Inter- and intraspecific patterns in resprouting of trees in undisturbed natural forests along an elevational gradient in Central Japan. Forests 9 (11): 672. Doi: 10.3390/f9110672.

Walteros, Ingrid; Molano, Deysi; Almanza, P. J. (2013). Efecto de la poda sobre la producción y calidad de frutos de Vitis vinifera L. Var. Sauvignon blanc en Sutamarchán - Boyacá. Orinoquia [online]. 17 (2): 167-176. ISSN 0121-3709. 